\title{
Sexual reproductive cycle of the epibiotic soft coral Alcyonium coralloides (Octocorallia, Alcyonacea)
}

\author{
Elena Quintanilla ${ }^{1, *}$, Josep-Maria Gili ${ }^{1}$, Pablo J. López-González ${ }^{2}$, \\ Georgios Tsounis ${ }^{1,4}$, Teresa Madurell ${ }^{1}$, Ida Fiorillo ${ }^{1}$, Sergio Rossi ${ }^{3}$ \\ ${ }^{1}$ Institut de Ciències del Mar, ICM-CMIMA (CSIC), 08003 Barcelona, Spain \\ ${ }^{2}$ Departamento de Zoología, Facultad de Biología, Universidad de Sevilla, 41012 Sevilla, Spain \\ ${ }^{3}$ Institut de Ciència i Tecnologia Ambientals, Universitat Autònoma de Barcelona, 08193 Cerdanyola del Vallés, Spain \\ ${ }^{4}$ Present address: Department of Ecology, Leibniz Center for Tropical Marine Ecology, 28359 Bremen, Germany
}

\begin{abstract}
Alcyonium coralloides is an epibiotic soft coral overgrowing living colonies of Mediterranean gorgonians. The main features of the sexual reproductive cycle of this soft coral species are described and quantified for the first time, in a population found at 18 to $22 \mathrm{~m}$ depth off the Medes Islands (NW Mediterranean). A. coralloides is a gonochoric internal brooder. The sexual cycle showed a single reproductive event per year. Gametogenesis took 5 to 6 mo, which is the shortest known gametogenesis in littoral octocorals (especially for oogenesis). The maximum mean \pm SD diameter was $365 \pm 86 \mu \mathrm{m}$ for spermatic cysts and $632 \pm 125 \mu \mathrm{m}$ for mature oocytes. Sperm was released in spring (late May). Average male and female fecundity in this last phase of the cycle was $15 \pm 9$ spermatic cysts and $7 \pm 4$ oocytes per polyp, respectively. Larvae of about $1000 \mu \mathrm{m}$ in length were observed in the gastrovascular cavities of female colonies in May, before they were released in June. We suggest that the remarkable short gametogenesis and timing shown by $A$. coralloides is an adaptation to optimize the colonization of its host (in this case the gorgonian octocoral Paramuricea clavata). We conclude that $A$. coralloides larvae could be ready to settle in early summer when the host $P$. clavata is probably more vulnerable as a result of its own reproductive cycle coming to an end.
\end{abstract}

KEY WORDS: Alcyonium coralloides Paramuricea clavata - Epibiosis - Reproductive effort · Soft corals $\cdot$ Reproductive coupling $\cdot$ Gametogenesis Resale or republication not permitted without written consent of the publisher

\section{INTRODUCTION}

Competition for substrate space is a key factor determining the survival of benthic species such as octocorals (Connell 1961, Pequegnat 1964, Paine 1974, Jackson 1977). Due to this dependence on the colonization of stable substrates (Gili \& Coma 1998), octocorals have developed mechanisms and strategies allowing them to successfully compete for the available substrate (Jackson 1977). Epibiosis is a biological relationship consisting of a non-parasitic organism spending at least 1 phase of its life cycle growing on a larger organism (Wahl 1989). This strat- egy is adopted by many species in highly structured and diversified benthic communities where competition for space is vital, as in Mediterranean coralligenous formations (Ros et al. 1985, Witman \& Dayton 2001).

Coralligenous formations are produced mainly by the accumulation of encrusting calcareous or coralline algae (Fredj \& Laubier 1985, Ballesteros 2006). Octocoral species such as Paramuricea clavata (Risso, 1826), Eunicella cavolinii (Kock, 1887), E. singularis (Esper, 1791), E. verrucosa (Pallas, 1766) and Corallium rubrum (Linnaeus, 1758) and soft coral genera such as Alcyonium are important architectural com- 
ponents of the coralligenous assemblages, increasing their biodiversity and complexity (Gili \& Ros 1984, Wendt et al. 1985, Sebens 1991, Tsounis et al. 2006). These organisms are highly vulnerable to environmental perturbations because their slow growth rates, low recruitment, sessile life form and exposed structural colonial forms imply slow recovery rates (Coma et al. 2004). Disturbances of anthropogenic origin include injuries due to contact with fishing lines, anchors or SCUBA divers that may result in decreased fecundity and increase opportunities for colonization by epibionts (Bavestrello et al. 1997, Tsounis et al. 2012). Furthermore, partial mortalities due to persistent heat waves may be an advantage for new settlers in the denuded skeletons (Cerrano et al. 2000).

The octocoral (Cnidaria, Anthozoa) Alcyonium coralloides (Pallas, 1766) is an epibiont species that grows by fouling ('runner' type) the apical axis of (most likely injured) colonies of gorgonians such as Paramuricea clavata, Eunicella singularis, E. cavolinii, E. verrucosa and Leptogorgia sarmentosa (Esper, 1789) (McFadden 1999, McFadden et al. 2001). The 'runner' type morphology consists of building encrusting tissue networks that show low physical resistance and a large area of tissue to the organism that horizontally colonizes a surface (Jackson 1979). The soft coral indirectly adopts a 3-dimensional morphology by exploiting the arboreal morphology of the gorgonian host species. The water flow is greater with increasing distance from the substrate (Butman 1987). Thus, having a 3-dimensional morphology and a distal position on the branches of gorgonians can be a trophic advantage for the epibiont. Exposure to higher water flow enhances both passive suspension feeding and evacuation of metabolic waste of colonies (Boero 1987, Wahl 1989). Thus, an epibiotic habit provides this soft coral with a favourable hydrodynamic position that confers greater volumetric water flow and more efficient suspension feeding (Best 1988).

The reproductive pattern is the main feature describing the life strategy of a species. For the first time, we describe the main quantitative parameters of the sexual reproductive cycle of Alcyonium coralloides and compare them to those of other littoral octocoral species. The genus Alcyonium presents a wide diversity of patterns in the mode of reproduction and sexuality (McFadden et al. 2001, Kahng et al. 2011). However, little is known about the sexual reproduction of these anthozoans, which play an essential role in benthic communities (Gili \& Coma 1998, Fautin 2002). We also investigated the implications of the epibiotic lifestyle of $A$. coralloides on its reproductive pattern. We hypothesized that the relatively simple colonial structure and reproductive strategy shown by A. coralloides (and other encrusting organisms) might be evolutionarily favoured due to its lower energetic needs when growing on other erect substrata (in the case of A. coralloides, the branches of Paramuricea clavata and other gorgonians). We argue that the ecological advantage of epibiont species in highly structured and diversified benthic communities can also be expressed in their reproductive pathway.

\section{MATERIALS AND METHODS}

Alcyonium coralloides samples were cut from colonized branches of Paramuricea clavata off Cova de la Vaca, within the Marine Protected Area of the Medes Islands (NW Mediterranean, $42^{\circ} 03^{\prime} \mathrm{N}, 3^{\circ} 15^{\prime} \mathrm{E}$ ) between 18 and $22 \mathrm{~m}$ depth. The sampling site is a large tunnel connecting 2 sides of one of the islets, and harbours a population of P. clavata. The abundance of $A$. coralloides is higher in this tunnel than usually found in other populations of $P$. clavata, due to the impact of SCUBA diving tourists that injure the corals, which thus favours colonization by $A$. coralloides (Tsounis et al. 2012). The tunnel is among the major SCUBA attractions along the Costa Brava and receives about 70000 visitors per yr (Lloret 2003, Coma et al. 2004).

Nine sampling trips were carried out by SCUBA diving between March 2008 and March 2009, usually monthly when weather conditions allowed the fieldwork. Twenty colony fragments of Alcyonium coralloides growing on the same number of colonies of Paramuricea clavata were collected in each sampling trip, yielding a total of 180 samples in the whole sampling period of this study. All samples were immediately fixed in buffered formalin (4\% in seawater). The collected colonies of $A$. coralloides were about $10 \mathrm{~mm}$ wide (coenenchyme covering the dead gorgonian axis) and ca. $50 \mathrm{~mm}$ long. We tried to sample the smallest fragments possible of $A$. coralloides, always from the apical part of the gorgonian branches, to minimize impact. Sampling was haphazard; however, because not many colonies were left to be sampled in the tunnel, we had to sample tissue from the same individuals repeatedly over time.

The colour pattern of Alcyonium coralloides colonies agrees with that described by Weinberg (1977) and morphotype M1 described by McFadden (1999): the sclerites of the coenenchyme were red, yellow in the tentacles and proximal part of the 

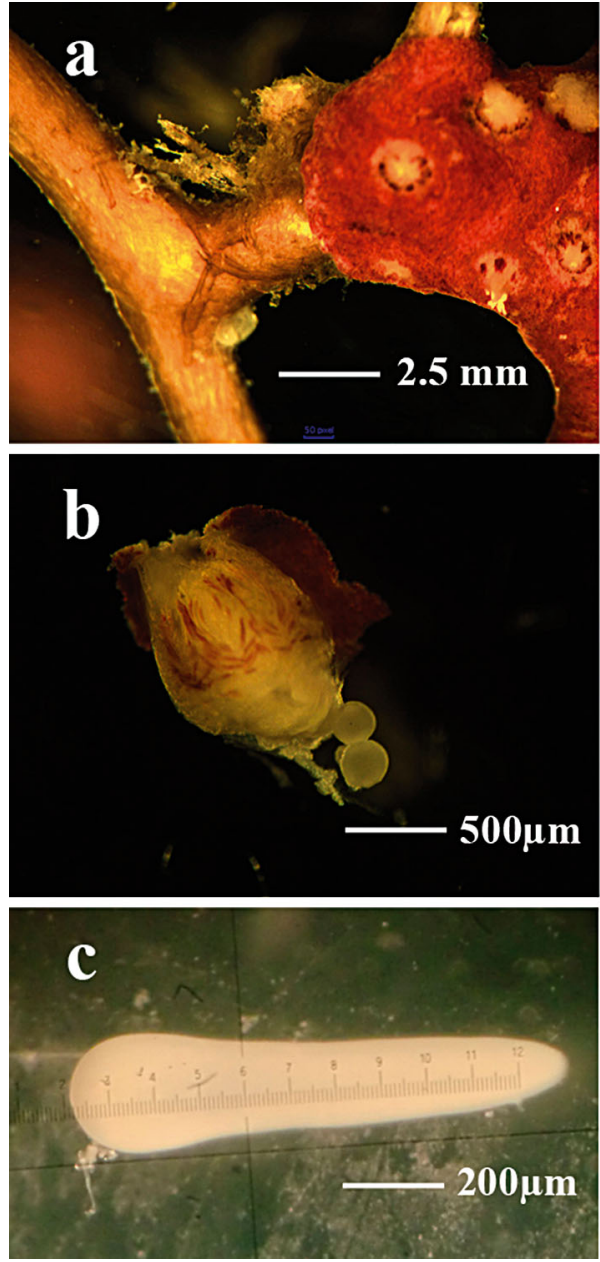

Fig. 1. (a) Colony of the epibiont Alcyonium coralloides on a branch of Paramuricea clavata. (b) Polyp from a male colony with spermatic cysts and (c) larvae of a female colony collected in May 2008

polyp, and red in the distal part of the polyp (Fig. 1a,b). Variability in colour patterns might exist, since white and pink colonies have been reported from deeper waters (Groot \& Weinberg 1982). A total of 900 polyps (5 polyps per collected colony) were opened to count and measure reproductive products (oocytes and spermatic cysts). The sampling effort, representing the minimum significant sample size for the number of colonies and polyps in males and females that had to be removed, was the same as that used in other studies on reproduction in Mediterranean octocorals (e.g. Coma et al. 1995). Sex determination was carried out by direct observation of reproductive products and confirmed by subsequent histological sections. Oocytes were yellow and firm, whereas male spermatic cysts were white and relatively fragile to manipulation.
A binocular stereomicroscope $(\times 20)$ was used for measuring the diameter of the oocytes and spermatic cysts. Polyps were dissected by removing the anthocodia to expose the gastrovascular cavity. The dissected polyps were chosen haphazardly. In each polyp, the diameter of the sexual products was counted and measured. The average diameter (minimum detection size $50 \mu \mathrm{m}$ ) and the average fecundity (number of oocytes or spermatic cysts per polyp) were obtained per sex and month. The size-frequency distributions of reproductive-product diameters and their average volume, measured as a sphere $\left(\mu \mathrm{m}^{3}\right.$ polyp $\mathrm{p}^{-1}$ ), were also analysed. Temperature data (20 $\mathrm{m}$ depth) were obtained from the meteorological station of l'Estartit every 3 to $4 \mathrm{~d}$.

In order to detect and monitor gametogenic and embryonic development, selected samples from both sexes in all sampled months were prepared for histological observations. Fragments were decalcified in a solution of $10 \%$ formic acid for a few minutes, rinsed in running water to remove excess acid in the tissues, dehydrated in a gradient of ethyl alcohols and then embedded in paraffin. Histological sections 6 to $8 \mu \mathrm{m}$ thick were stained with Ramón y Cajal's Triple Stain (Gabe 1968).

\section{RESULTS}

\section{Sexual cycle}

Alcyonium coralloides is gonochoric, with all polyps of a colony of the same sex. Larvae were found inside polyps of female colonies in May 2008 (Fig. 1c). Although the reproductive cycle was annual, gametogenesis lasted only 5 to 6 mo. Based on presence and subsequent absence of larvae from May to June, larval release was inferred. However, spermatic cysts were present in May (Fig. 2a) in the gastrovascular cavities of male colonies. The maximum monthly (mean $\pm \mathrm{SD}$ ) spermatic cyst diameter observed was $365 \pm 86 \mu \mathrm{m}$, and $632 \pm 125 \mu \mathrm{m}$ for mature oocytes in female colonies (Fig. 2). Both maximum values occurred in May, the last month of the gametogenic cycle. Also in this month fecundity (mean \pm SD) was $15 \pm 9$ spermatic cysts polyp ${ }^{-1}$ in male colonies, and $7 \pm 4$ oocytes polyp ${ }^{-1}$ in females (Fig. 3).

\section{Gametogenic cycle}

Spermatic cysts and oocytes showed an annual cycle of development, with internal fertilization of 

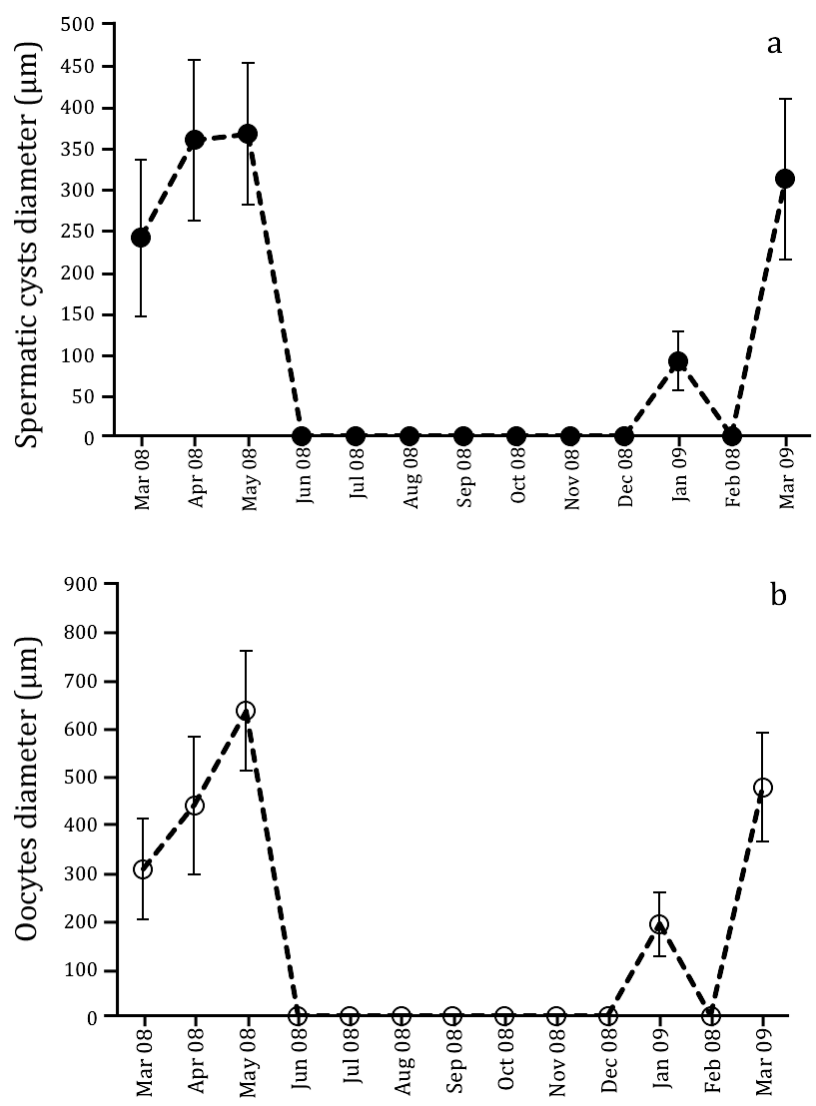

Fig. 2. Alcyonium coralloides. Diameter (mean $\pm \mathrm{SD}$ ) of (a) spermatic cysts and (b) oocytes in samples collected during 2008 and 2009

the oocytes and release of larvae in May. In both sexes, generation and development of reproductive products took 5 to $6 \mathrm{mo}$, probably beginning in December (no samples available) and ending with the release of sperm and larvae in May. In both males and females, the first evidence of small reproductive products $(0-100 \mu \mathrm{m})$ was found in January, possibly marking the onset of oogenesis in the previous month (Figs. 4 \& 5). Reproductive products of intermediate size classes $(300-400 \mu \mathrm{m})$ were also present in females, but smaller sizes were found in males (100-200 $\mu \mathrm{m})$.

In male colonies, the diameter (mean $\pm \mathrm{SD}$ ) of spermatic cysts increased by $34 \%$ between March 2008 $(240 \pm 95 \mu \mathrm{m})$ and May $2008(365 \pm 86 \mu \mathrm{m})$, just prior to the release of male sexual products (Fig. 2a). In January 2009, the first spermatic cysts were detected, with a diameter of $91 \pm 36 \mu \mathrm{m}$; they achieved a final diameter of $311 \pm 97 \mu \mathrm{m}$ in March 2009 (Fig. 2a). No spermatic cysts were found in samples between June and November 2008. Polyp fecundity decreased from (mean $\pm \mathrm{SD}$ ) $34 \pm 15$ to $15 \pm 9$ spermatic cysts polyp ${ }^{-1}$
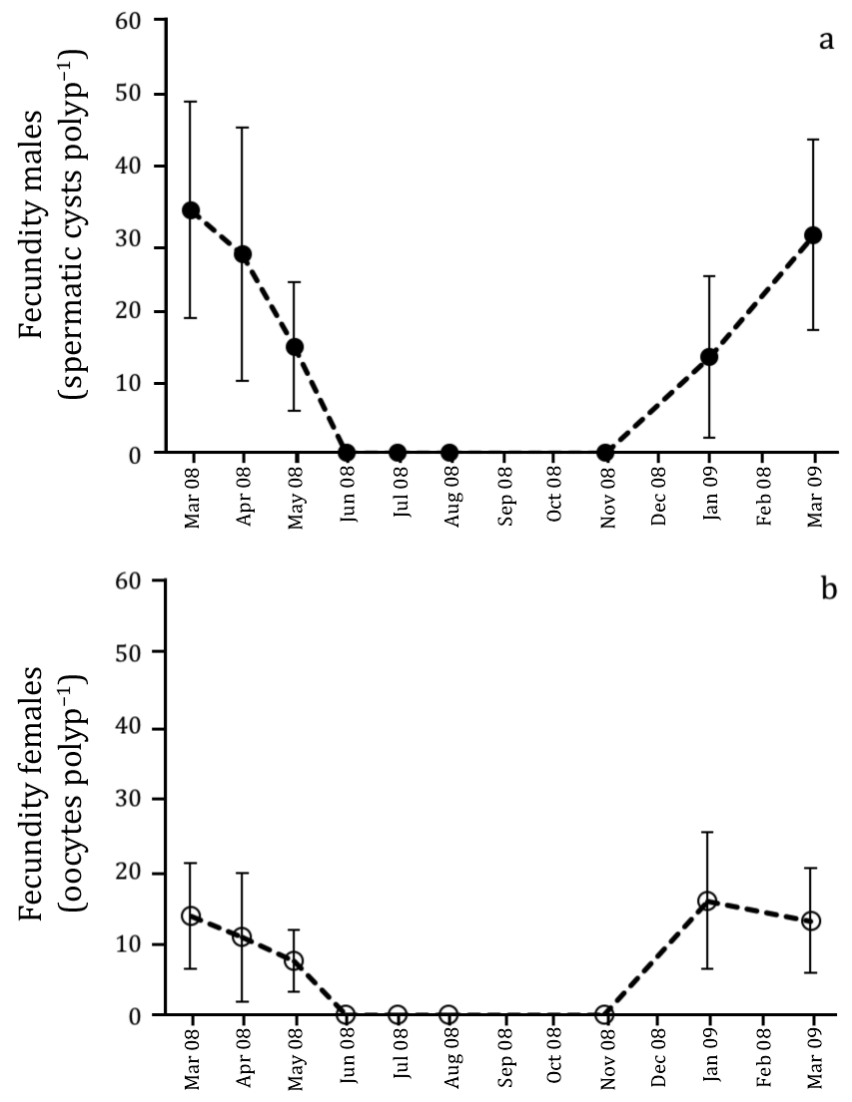

Fig. 3. Alcyonium coralloides. Fecundity (mean \pm SD) of (a) male and (b) female colonies collected during 2008 and 2009

between March and May 2008, but increased 56\% between January and March 2009 (13 \pm 11 and $30 \pm$ 13 spermatic cysts polyp ${ }^{-1}$, respectively; Fig. 3a).

The average oocyte diameter in female colonies doubled in size over $2 \mathrm{mo}$, from $304 \pm 105 \mu \mathrm{m}$ in March 2008 to $632 \pm 125 \mu \mathrm{m}$ in May 2008 (Fig. 2b). During June, July, August and November of 2008, no oocytes were found in female colonies. In January 2009, the average size of oocytes was $191 \pm 66 \mu \mathrm{m}$, increasing $60 \%$ up to $475 \pm 113 \mu \mathrm{m}$ in March 2009 (Fig. 2b). The fecundity decreased by $46 \%$ in March and May 2008, whereas the highest fecundity was observed during January $2009(16 \pm 9$ oocytes poly $\mathrm{p}^{-1}$ ) and then decreased by $15 \%$ (13 \pm 7 oocytes polyp $^{-1}$ in March 2009; Fig. 3b).

The average volume $\left(\mu \mathrm{m}^{3}\right.$ polyp $\left.^{-1}\right)$ of spermatic cysts and oocytes (Fig. 6) increased with development; the average diameter of both sexes followed the same pattern. Temperature was registered between March 2008 and March 2009 (Fig. 7).

The histological study showed that gametogenesis probably started in December: all male and female 


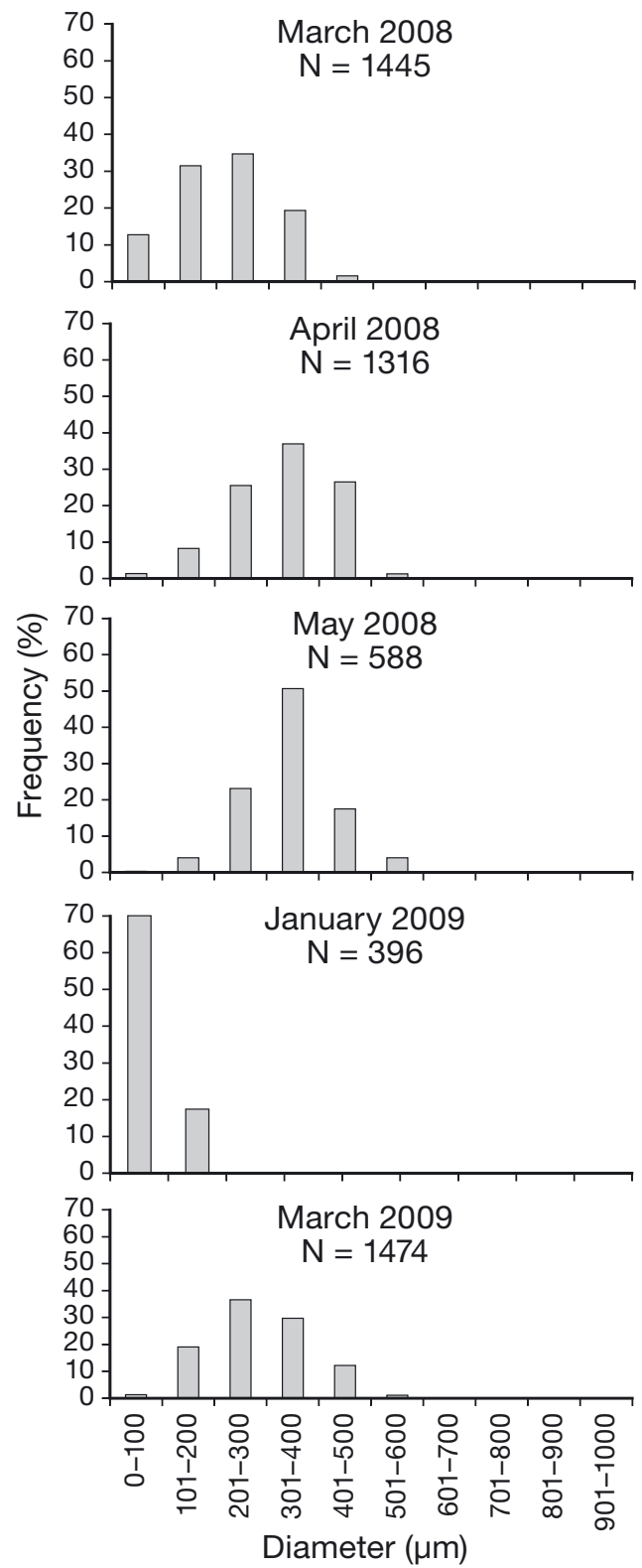

Fig. 4. Alcyonium coralloides. Distribution of spermatic cyst diameter $(\mu \mathrm{m})$ frequencies in male colonies collected during 2008 and 2009. N: total number of spermatic cysts measured per month

colonies sampled in November lacked reproductive products, whereas in the following sampled month (January), previtellogenic oocytes between 50 and $70 \mu \mathrm{m}$ (Fig. 8b) and vitellogenic oocytes with increasing amount of lipid drops in the ooplasm (Fig. 8c,d) were present. Starting in January, male colonies showed spermatic cysts, which were present in all inspected male colonies in the following months. Spermatic cysts showed numerous heads of developing sperm and a thinner mesogleal envelope than oocytes (Fig. 9). Male colonies examined at the

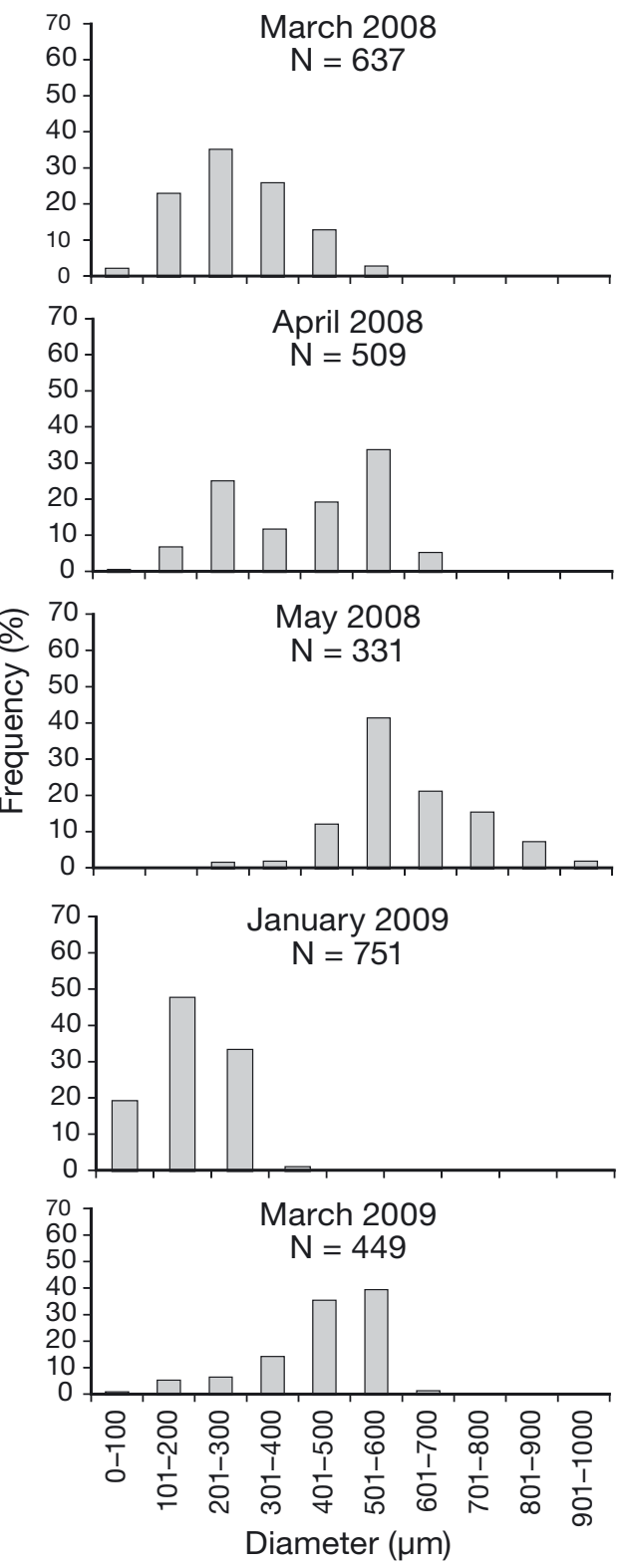

Fig. 5. Alcyonium coralloides. Distribution of oocyte diameter $(\mu \mathrm{m})$ frequencies in female colonies collected during 2008 and 2009. N: total number of oocytes measured per month

end of the cycle (May) were heterogeneous; the gastrovascular cavities of some colonies were completely empty (indicating the emission of spermatic cysts or sperm), whereas others still had some completely mature spermatic cysts full of sperm. Oocytes increased in size until May, when a few oocytes (some devoid of their mesogleal cover, and others still inside mesogleal capsules) but mainly larvae (showing epidermis with columnar cells and disaggregated internal yolk granular reserves) were observed in the gastrovascular cavities of polyps of female colonies. 


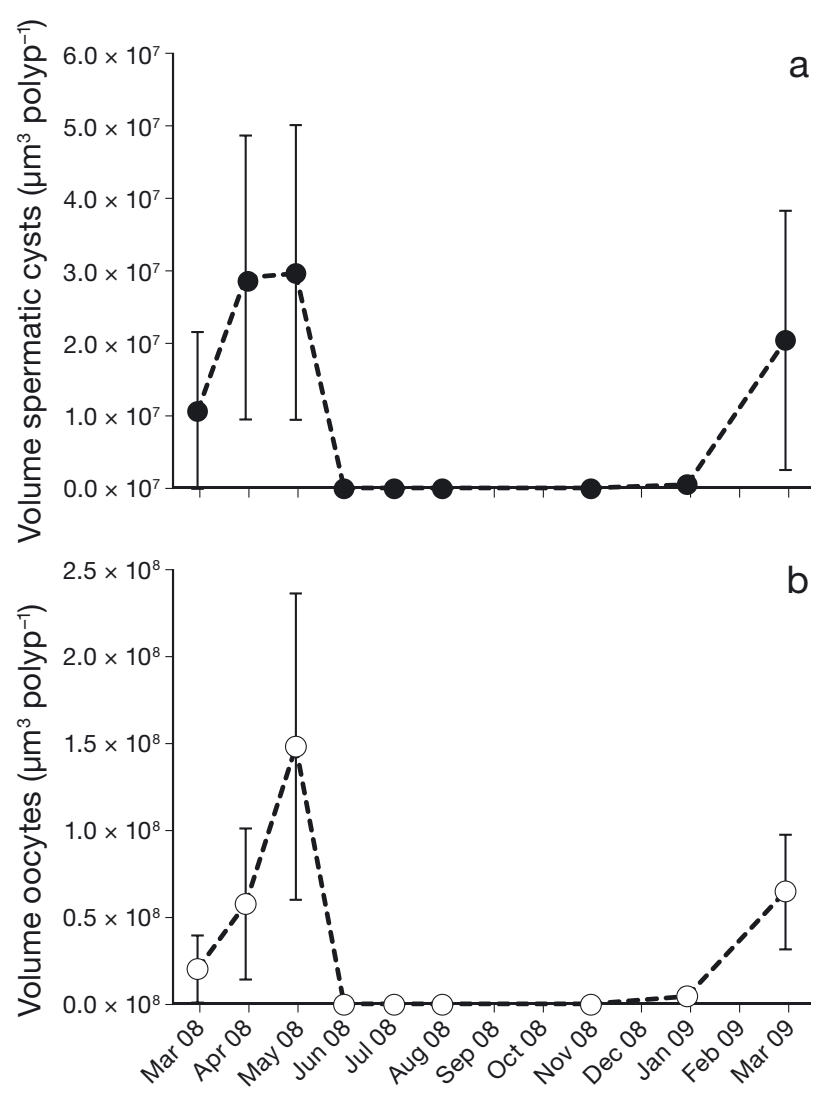

Fig. 6. Alcyonium coralloides. Volume for (a) total spermatic cyst content per polyp (male colonies) and (b) total oocyte content per polyp (female colonies) of samples collected during 2008 and 2009

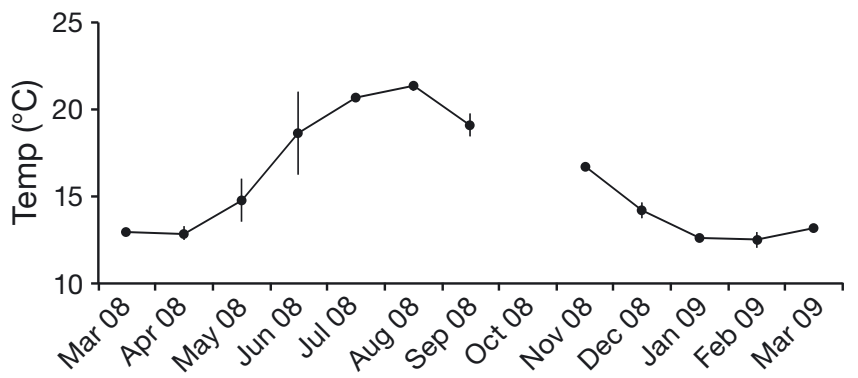

Fig. 7. Water temperature $\left({ }^{\circ} \mathrm{C}\right)$ at $20 \mathrm{~m}$ depth between March 2008 and March 2009

\section{DISCUSSION}

Similar to several other Alcyonium species (6 out of 12, according to Kahng et al. 2011), A. coralloides is a gonochoric species (Groot \& Weinberg 1982). Gonochorism is the most common reproductive strategy in Octocorallia (70\% according to Kahng et al. 2011), while hermaphroditism is the most common pattern among tropical scleractinian hexacorals (Harrison \&
Wallace 1990, Kahng et al. 2011). A. coralloides is considered an internal brooder, and thus is characterized by internal fertilization and retention of larvae in the gastrovascular cavity of the polyps (Giese \& Pearse 1974, McFadden et al. 2001). Internal brooding is the most common strategy among Alcyonium species (Kahng et al. 2011), whereas broadcast spawning is most common in tropical soft corals (Alino \& Coll 1989, Cordes et al. 2001, Hwang \& Song 2007, Kahng et al. 2011), and surface brooders are not common (Hwang \& Song 2007, Kahng et al. 2011, Fiorillo et al. 2013).

\section{Gametogenesis}

Alcyonium coralloides showed an annual reproductive cycle, characterized by fast gametogenic development of similar duration for both sexes and an early release of larvae in spring (probably completing it in late May since larvae were absent in the samples from June). Our data revealed a shorter cycle (by $2 \mathrm{mo}$ ) in A. coralloides than that observed in other Alcyonium species and Mediterranean littoral octocorals (Table 1, Kahng et al. 2011). However, because variability of the reproductive cycle may occur due to local or regional environmental conditions (e.g. temperature, food availability, other biological variables), more than $1 \mathrm{yr}$ of observations is needed to support these results. Weinberg (1977) observed small oocytes (as eggs in his study) in specimens of $A$. coralloides (as Parerythropodium coralloides) collected in November, whereas Lacaze-Duthiers (1900) (as Sympodium coralloïdes) mentioned May to July as the reproductive period, and Lo Bianco (1909, as cited by Weinberg 1977) obtained larvae in the aquarium in June.

Gametogenesis of male and female colonies had similar duration (5 to $6 \mathrm{mo}$ ), and oogenesis was shorter than that of other octocorals. In fact, the general tendency in octocorals is an oogenesis that lasts longer than spermatogenesis (Benayahu \& Loya 1984, 1986, Benayahu et al. 1990). This is also the general tendency among scleractinian hexacorals (Harrison \& Wallace 1990, Harrison 2011) and is explained by the fact that oogenesis requires more time and energy than spermatogenesis because these lecitotrophic species develop mature oocytes with a great amount of yolk. These reserves will be the source of energy for sustaining larval development (Vance 1973). For instance, oogenesis in Mediterranean gorgonians such as Eunicella singularis, Leptogorgia sarmentosa and Paramuricea clavata 

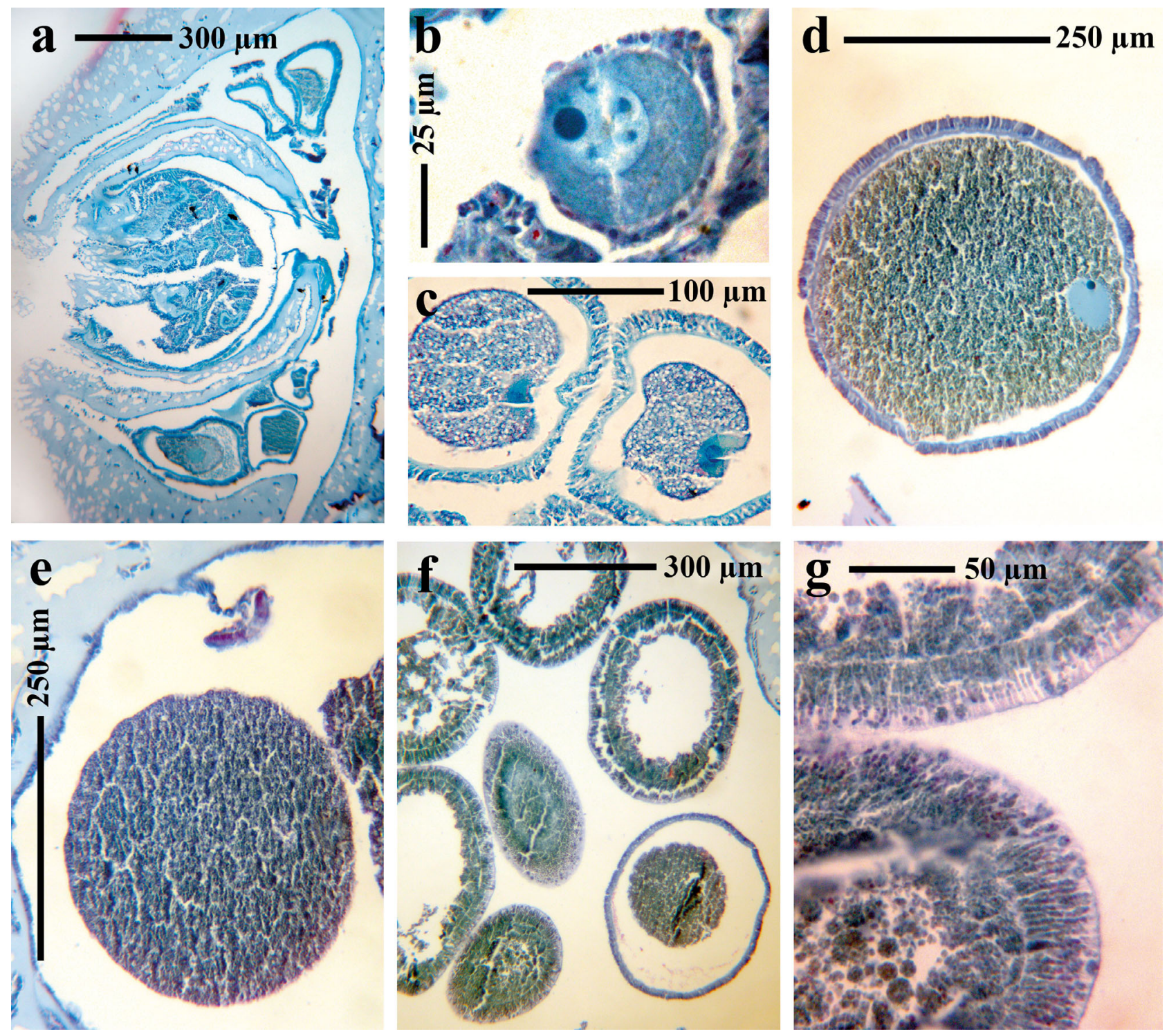

Fig. 8. Alcyonium coralloides. Histological sections of female colonies: (a) retracted polyp with oocytes in the gastrovascular cavity, (b) previtellogenic oocyte ca. $50 \mu \mathrm{m}$ in diameter, (c) vitellogenic oocytes with the ooplasm increasing in drops of yolk, (d) oocyte (mature or close to maturity), still inside mesogleal capsule, (e) mature oocyte free in the gastrovascular cavity, without parental mesogleal capsule, (f) interior of a gastrovascular cavity showing a group of larvae with diverse amount of disaggregating reserves, and an oocyte still in its mesogleal capsule, (g) detail of the epithelia of adjacent larvae, showing typical columnar epidermis and a thin mesogleal layer separating it from their incipient gastrodermis

lasts 13 to $17,>12$ and 13 to 18 mo, respectively, whereas spermatogenesis lasts 5 to 7 mo (Table 1). This trend is also characteristic in the soft coral Alcyonium acaule in the same area, with oogenesis and spermatogenesis lasting for 12 to 13 mo (Fiorillo et al. 2013; Table 1). In encrusting soft corals, this trend also appears in species such as Rhytisma fulvum fulvum (Forskål, 1775) (Parerythropodium fulvum fulvum; Benayahu \& Loya 1983), in which oogenesis lasts 10 to $11 \mathrm{mo}$, while spermatogenesis lasts 7 to 9 mo. Our results also showed an increase in average volume of spermatic cysts and oocytes with a concurrent decrease in average fecundity during gametogenic development. This could be partially explained by absorption of the smallest generated sexual products in favour of the development of other spermatic cysts and oocytes that subsequently end their gametogenic cycle (Fiorillo et al. 2013). 

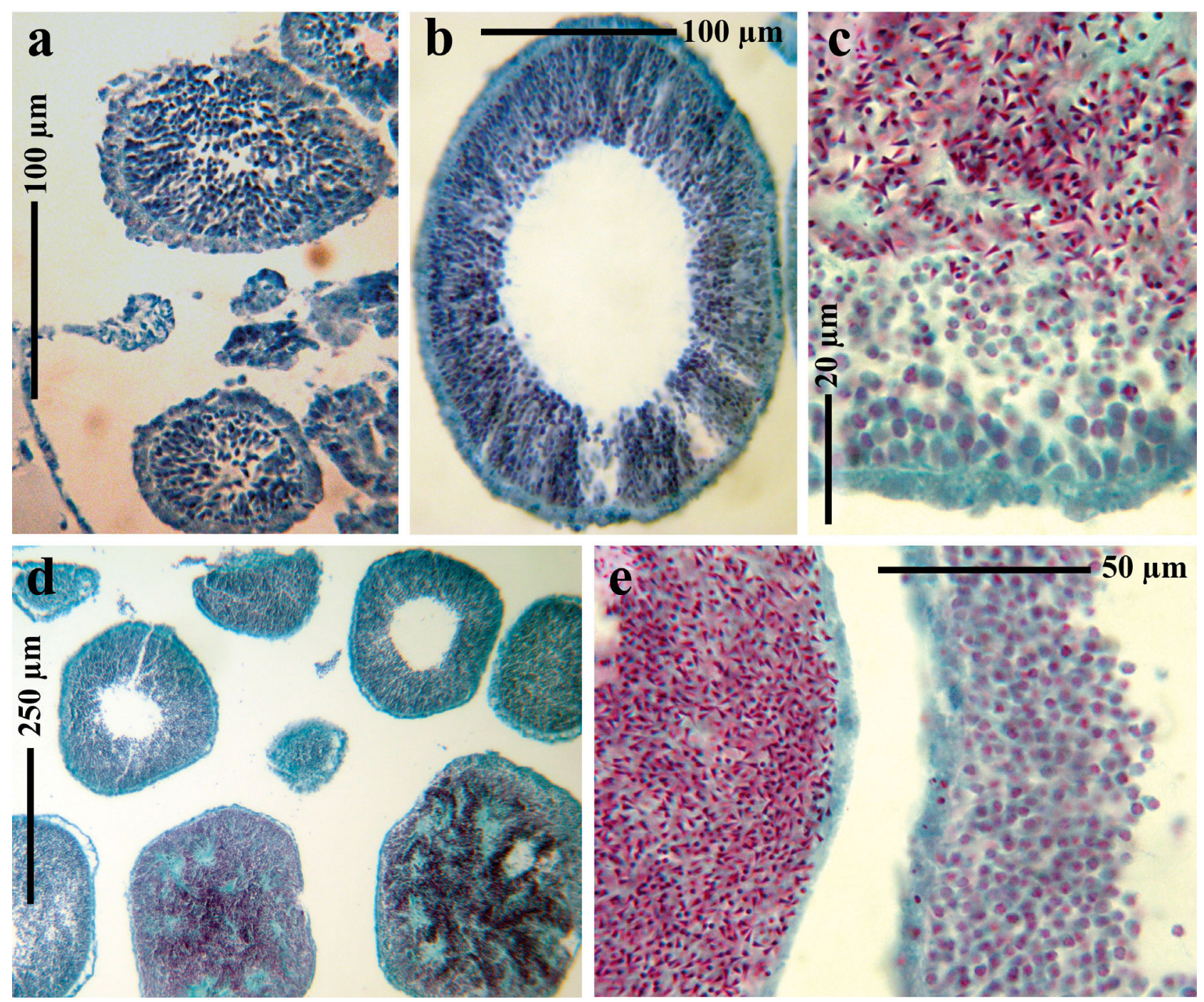

Fig. 9. Alcyonium coralloides. Histological sections of male colonies: (a) early spermatic cysts, without clear distinct lumen and disorganized spermaries, (b) developing spermatic cyst with typical lumen and future sperm flagellae and head of immature sperm still rounded and radially arranged, (c) developing spermatic cyst showing all maturation stages of the sperm heads, from rounded bodies (on the periphery of the cyst; bottom of the image), more concentrated (centre of the image) and fully defined and mature sperm heads, distinctly triangular and strongly stained (in the most internal parts of the cyst; upper part of the image), (d) interior of a gastrovascular cavity of a colony collected in April, showing spermatic cysts in different stages of development (sperm heads at the bottom of the image are strongly stained, denoting an advanced stage of maturation), (e) two adjacent spermatic cysts from a colony collected in April, showing the asynchrony in the development of cysts (the one on the left is fully developed, with disorganized sperm heads reaching the parental mesogloeal capsular layer, while the one on the right still contains rounded immature sperm heads)

\section{Release of male sexual products}

The synchronization of both sexes in the release of sexual products is a common trend among broadcastspawning octocorals that allows maximizing the fertilization success (Alino \& Coll 1989). This synchronization is promoted by external factors such as temperature (Grigg 1977) and lunar cycle (Brazeau \& Lasker 1989, 1990). In subtropical alcyonaceans, the release of male gametes coincides with increased water temperature in late spring (e.g. Eunicella singularis, Paramuricea clavata, Sarcophyton glaucum (Quoy \& Gaimard, 1833), Alcyonium acaule Linnaeus, 1758; see Coma et al. 1995, Benayahu \& Loya 1986, Ribes et al. 2007, Fiorillo et al. 2013). In the case of E. singularis, male gametes are released in May to June, fertilization is internal, and release of larvae occurs in June to July (Ribes et al. 2007). The release 


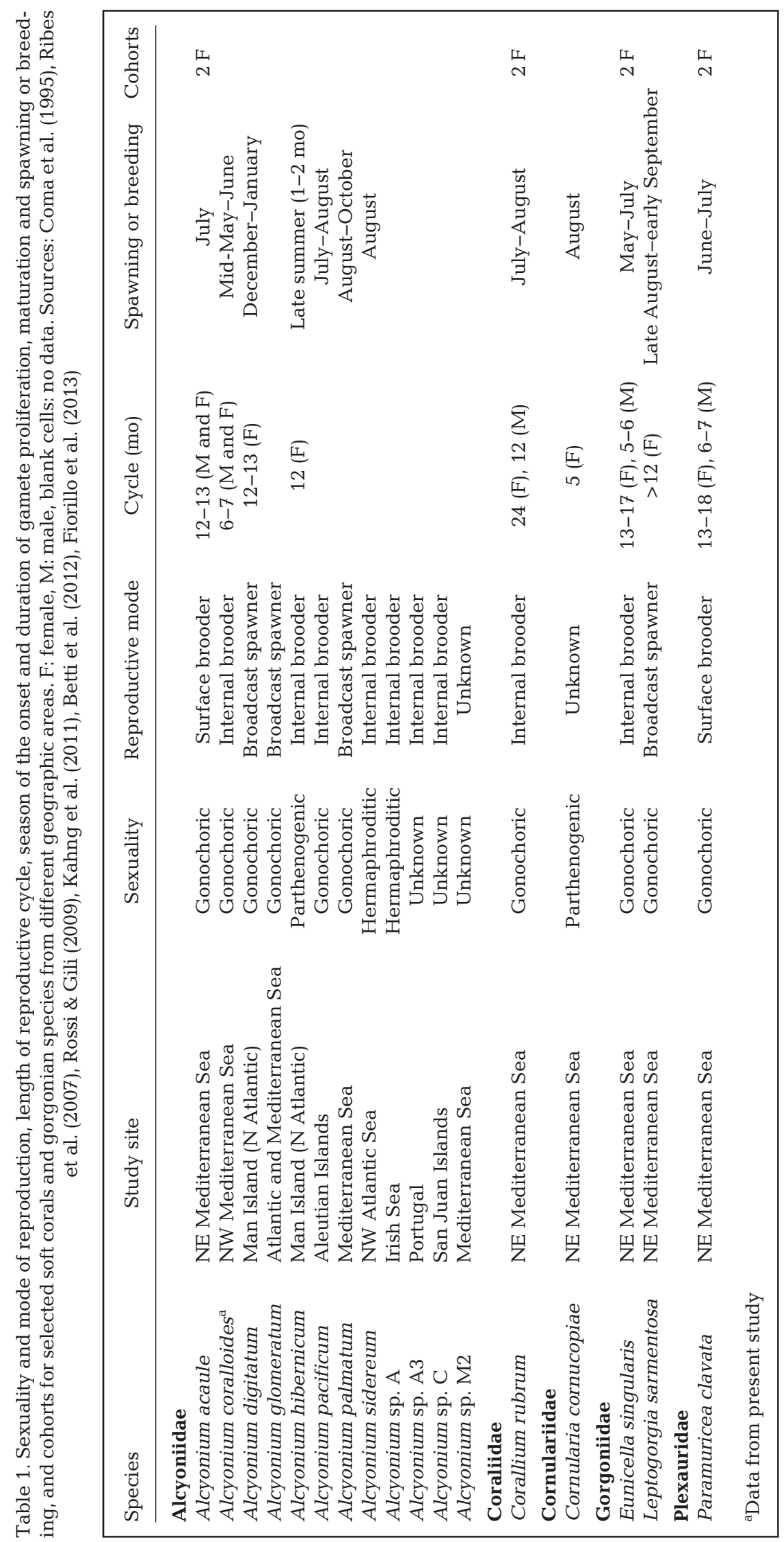

of sperm in A. coralloides occurs from mid-May on, while the oocytes are retained in the female polyp for internal ripening and fertilization. This release of sperm coincides with a $2^{\circ}$ increase in water temperature (from 14.8 to $16.7^{\circ} \mathrm{C}$ between 14 and 21 May 2008, Fig. 7), but it appears to precede spawning in other Alcyonium species and Mediterranean octocorals (see Table 1).

\section{Release of larvae}

In octocorals, less than $1 \mathrm{wk}$ is enough for the transition from zygote to planula (Alino \& Coll 1989, Babcock 1990, Gutierrez-Rodríguez \& Lasker 2004). Internal fertilization and planulae development might occur in a short period, as is the case of Paramuricea clavata, in which blastulae developed in $24 \mathrm{~h}$ and planulae appeared after 48 to $72 \mathrm{~h}$ (Linares et al. 2008). As mentioned above, the release of Alcyonium coralloides larvae probably occurs in May to early June (larvae were completely absent in samples collected in June (see Figs. 2b, $3 b, 5, \& 6 b)$. Although unknown for the majority of octocoral species, some anthozoan larvae are already competent $2 \mathrm{~h}$ after release, whereas other larvae require several days (Atoda 1947, Harii \& Kayanne 2003). Thus, it is plausible that larvae of $A$. coralloides are ready to settle on naked segments of $P$. clavata axes if these are available. Denudation can occur through biological (depredation by gastropod molluscs, e.g. Simnia and Coralliophilia species; Crocetta \& Spanu 2008) or environmental causes (mortality events and diseases linked to climate warming; see Cerrano et al. 2000, Linares et al. 2008, Coma et al. 2009, Garrabou et al. 2009) or due to physical damage (e.g. excessive SCUBA diving activities in particular areas, fishing nets and lines; see Harmelin \& Marinopoulos 1994, Tsounis et al. 2012), as occurred at our study site. 


\section{Epibiotic strategy of Alcyonium coralloides}

There are similarities between the reproductive patterns of A. coralloides and some zoanthids. Most zoanthid species also grow in fouling form as encrusting colonies on hard substrates or as epibionts on other organisms (e.g. sponges, hydrozoans, gorgonians, antipatharians; Ryland \& Westphalen 2004, Previati et al. 2010, Sinniger et al. 2010). These species rarely reproduce sexually or do so in a short period, as asexual reproduction is the fastest way of covering substrate (Ryland \& Babcock 1991, Garrabou 1999). A short gametogenesis (oogenesis) is shared among zoanthids: 4 to $5 \mathrm{mo}$ in the genus Protopalythoa, 5 to 6 mo in P. parasiticus (Duchassaing \& Michelotti, 1860) and 8 mo in P. axinellae (Schmidt, 1862) (Ryland \& Babcock 1991, Ryland et al. 2000, Ryland \& Westphalen 2004, Previati et al. 2010). A recent study in the Adriatic Sea (Betti et al. 2012) showed that in the octocoral Cornularia cornucopiae (Pallas, 1766), an epibiont growing over ascidians and sponges, oogenesis occurs from March to August. This pattern coincides with the remarkably short oogenesis of A. coralloides, suggesting that a short gametogenesis could be a common feature of epibiont fouling species. Epibiont species (defined by Wahl 1989) show fast growth, sexual reproduction limited to short and seasonal periods (Coma et al. 1992, 1998) and asexual reproduction (Faucci \& Boero 2000). These are features of opportunistic species ('r strategy'; Jackson 1977) and are consistent with the epibiosis strategy, for which the main priority is to persist under high levels of spatial competition.

The lack of reproductive products during 6 mo in Alcyonium coralloides suggests that energy is invested into processes other than sexual reproduction (such as growth and maintenance), or environmental conditions do not permit investments in reproductive tasks for this epibiotic species. In zoanthids, it seems that the short gametogenesis means a higher energetic investment towards asexual reproduction, leading to faster growth of the colony, and thus to higher height over the substrate (Rossi et al. 2012). In any case, shortening the reproductive cycle implies a significant advantage in substrate colonization.

The release of larvae by Alcyonium coralloides occurred before the gamete output of Paramuricea clavata (Coma et al. 1995). In the Mediterranean, many suspension feeders show aestivation (Coma et al. 2000). The summer trophic crisis leads to relative inactivity of anthozoans (Coma et al. 1998, Garrabou 1999). Minimum levels of protein, carbohydrates and lipid concentration, as well as a notable expression of stress proteins (HSP 70 and 90) related with trophic constraints in summer (beginning in June), support this seasonal variation of the ecophysiological parameters for the basibiont P. clavata (Rossi et al. 2006, Gori et al. 2007). Due to the minimum levels of food intake in $P$. clavata in summer, energy investment into reproduction is concentrated in spring (March and June) when conditions of food availability are more favourable (Coma et al. 1998). The breeding period takes place between June and July, afterwards leaving colonies exhausted and more vulnerable to potential colonization aggressions like that caused by the larval settlement of $A$. coralloides. Furthermore, $P$. clavata is a surface brooder; females secrete a mucus that bounds the eggs together and keeps them adhered to the surface of the mother colony (Coma et al. 1995). Thus the timing of reproduction in A. coralloides can also be regarded as an adaptive strategy that allows successful colonization of the gorgonian axes, avoiding $P$. clavata secretions, which would impede its own larval settlement. The related species Rhytisma fulvum fulvum, also a soft coral encrusting species although not an epibiont, has comparatively longer oogenesis (Benayahu \& Loya 1983).

The reproductive cycle of the epibiont Alcyonium coralloides seems to be evolutionarily coupled to that of its gorgonian basibiont, allowing the presence of both species in Mediterranean ecosystems. A shorter reproductive cycle in A. coralloides implies a significant advantage in substrate colonization during a period of the year when the basibiont decreases activity as a result of the high cost of its own reproduction and less favourable trophic environmental conditions.

Acknowledgements. We are especially grateful to J. Pascual for environmental data collection, E. Rodriguez from the American Museum of Natural History, NY, for reviewing the text and the reviewers who critically read the manuscript and helped to improve the document with their comments. This work was partially funded by the program LIFE+INDEMARES (LIFE07 NAT/E/000732-'Inventariación y designación de la red Natura 2000 en áreas marinas del estado español'). Partial support was provided to T.M. by a JAEDoc (Consejo Superior de Investigaciones Científicas, SPAIN) grant; S.R. was funded by a Ramón y Cajal contract (RYC-2007-01327).

\section{LITERATURE CITED}

Alino PM, Coll JC (1989) Observations of the synchronized mass spawning and post settlement activity of octocorals on the Great Barrier Reef, Australia: biological aspects. Bull Mar Sci 45:697-707 
Atoda K (1947) The larva and postlarval development of some reef-building corals. I. Pocillopora damicornis cespitosa (Dana). Sci Rep Tohoku Univ Fourth Ser (Biol) 18: 24-47

Babcock R (1990) Reproduction and development of the blue coral Helipora coerulea (Alcyonaria: Coenothecalia). Mar Biol 104:475-481

Ballesteros E (2006) Mediterranean coralligenous assemblages: a synthesis of present knowledge. Oceanogr Mar Biol Annu Rev 44:123-195

Bavestrello G, Cerrano C, Zanzi D, Cattaneo-Vietti R (1997) Damage by fishing activities to the Gorgonian coral Paramuricea clavata in the Ligurian Sea. Aquat Conserv 7:253-262

> Benayahu Y, Loya Y (1983) Surface brooding in the Red Sea soft coral Parerythropodium fulvum fulvum (Forskaal, 1775). Biol Bull (Woods Hole) 165:353-369

> Benayahu Y, Loya Y (1984) Life history studies of the red sea soft coral Xenia macrospiculata Gohar, 1940. I. Annual dynamics of gonadal development. Biol Bull (Woods Hole) 166:32-43

- Benayahu Y, Loya Y (1986) Sexual reproduction of a soft coral: synchronous and brief annual spawning of SarCophyton glaucum (Quoy and Gaimard, 1833). Biol Bull (Woods Hole) 170:32-42

Benayahu Y, Weil D, Kleinman M (1990) Radiation of broadcasting and brooding patterns in coral reef alcyonaceans. Adv Invertebr Reprod 5:323-328

Best B (1988) Passive suspension feeding in a sea pen: effects of ambient flow on volume flow rate and filtering efficiency. Biol Bull (Woods Hole) 175:332-342

Betti F, Bo M, Di Camillo CG, Bavestrello G (2012) Life history of Cornularia cornucopiae (Anthozoa: Octocorallia) on the Conero Promontory (North Adriatic Sea). PSZNI: Mar Ecol 33:49-55

Boero F (1987) Evolutionary implications of habitat selection in the hydroids of Posidonia oceanica meadows. In: Bouillon J, Boero F, Cicogna F, Cornelius PFS (eds) Modern trends in the systematics, ecology, and evolution of hydroids and hydromedusae. Clarendon Press, Oxford, p 251-256

Brazeau DA, Lasker HR (1989) The reproductive cycle and spawning in a Caribbean gorgonian. Biol Bull (Woods Hole) 176:1-7

Brazeau DA, Lasker HR (1990) Sexual reproduction and external brooding by the Caribbean gorgonian Briareum asbestinum. Mar Biol 104:465-474

Butman CA (1987) Larval settlement of soft-sediment invertebrates: the spatial scales of pattern explained by active habitat selection and the emerging role of hydrodynamical processes. Oceanogr Mar Biol Annu Rev 25:113-165

Cerrano C, Bavestrello G, Bianchi CN, Cattaneo-Vietti R and others (2000) A catastrophic mass-mortality episode of gorgonians and other organisms in the Ligurian Sea (northwestern Mediterranean), summer 1999. Ecol Lett 3:284-293

Coma R, Llobet I, Zabala M, Gili JM, Hughes RG (1992) The population dynamics of Halecium petrosum and Halecium pusillum (Hydrozoa, Cnidaria), epiphytes of Halimeda tuna in the northwestern Mediterranean. Sci Mar 56:161-169

Coma R, Ribes M, Zabala M, Gili JM (1995) Reproduction and cycle of gonadal development in the Mediterranean gorgonian Paramuricea clavata. Mar Ecol Prog Ser 117: 173-183
Coma R, Ribes M, Gili JM, Zabala M (1998) An energetic approach to the study of life-history traits of two modular colonial benthic invertebrates. Mar Ecol Prog Ser 162: 89-103

Coma R, Ribes M, Gili JM, Zabala M (2000) Seasonality in coastal benthic ecosystems. Trends Ecol Evol 15:448-453

> Coma R, Pola E, Ribes M, Zabala M (2004) Long-term assessment of temperate octocoral mortality patterns, protected vs. unprotected areas. Ecol Appl 14:1466-1478

> Coma R, Ribes M, Serrano E, Jiménez E, Salat J, Pascual J (2009) Global warming-enhanced stratification and mass mortality events in the Mediterranean. Proc Natl Acad Sci USA 106:6176-6181

> Connell JH (1961) The influence of interspecific competition and other factors on the distribution of the barnacle Chthamalus stellatus. Ecology 42:710-723

> Cordes EE, Nybakken JW, VanDykhuizen G (2001) Reproduction and growth of Anthomastus ritteri (Octocorallia: Alcyonacea) from Monterey Bay, California, USA. Mar Biol 138:491-501

Crocetta F, Spanu M (2008) Molluscs associated with a Sardinian deep water population of Corallium rubrum (Linné, 1758). Mediterr Mar Sci 9:63-85

de Lacaze-Duthiers H (1900) Coralliaires du Golfe du Lion. Alcyonaires. Arch Zool Exper Gen 3:353-462

Faucci A, Boero F (2000) Structure of an epiphytic hydroid community on Cystoseira at two sites of different wave exposure. Sci Mar 64:255-264

Fautin DG (2002) Reproduction of Cnidaria. Can J Zool 80: 1735-1754

Fiorillo I, Rossi S, Alva V, Gili JM, López-González PJ (2013) Seasonal cycle of sexual reproduction of the Mediterranean soft coral Alcyonium acaule (Anthozoa, Octocorallia). Mar Biol 160:719-728

Fredj G, Laubier L (1985) The deep Mediterranean benthos. In: Moratou-Avostolopoulou M, Kiortsis V (eds) Mediterranean marine ecosystems. Plenum Press, New York, NY, p 109-145

Gabe M (1968) Technique histologique. Massouet et Cie, Paris

> Garrabou J (1999) Life-history traits of Alcyonium acaule and Parazoanthus axinellae (Cnidaria, Anthozoa) with emphasis on growth. Mar Ecol Prog Ser 178:193-204

Garrabou J, Coma R, Bensoussan N, Bally P and others (2009) Mass mortality in Northwestern Mediterranean rocky benthic communities: effects of the 2003 heat wave. Glob Change Biol 15:1090-1103

Giese AC, Pearse JS (1974) Introduction: general principles. In: Giese AC, Pearse JS (eds) Reproduction of marine invertebrates. Acoelomate and pseudocoelomate metazoans, Vol 1. Academic Press, New York, NY, p 1-49

Gili JM, Coma R (1998) Benthic suspension feeders: their paramount role in littoral marine food webs. Trends Ecol Evol 13:316-321

Gili JM, Ros JD (1984) L'estatge circalitoral de les Illes Medes: el coral.ligen. In: Ros JD, Olivella JM, Gili JM (eds) Els sistemes naturals de les Illes Medes. Institut d'Estudis Catalans, Barcelona, p 677-705

Gori A, Linares C, Rossi S, Coma R, Gili JM (2007) Spatial variability in reproductive cycle of the gorgonians Paramuricea clavata and Eunicella singularis (Anthozoa, Octocorallia) in the Western Mediterranean Sea. Mar Biol 151:1571-1584

Grigg RW (1977) Population dynamics of two gorgonian corals. Ecology 58:278-290 
Groot S, Weinberg S (1982) Biogeography, taxonomical status and ecology of Alcyonium (Parerythropodium) coralloides (PALLAS, 1766). PSZNI: Mar Ecol 3:293-312

Gutierrez-Rodríguez C, Lasker HR (2004) Microsatellite variation reveals high levels of genetic variability and population structure in the gorgonian coral Pseudopterogorgia elisabethae across the Bahamas. Mol Ecol 13: 2211-2221

Harii S, Kayanne H (2003) Larval dispersal, recruitment, and adult distribution of the broody stony octocoral Heliopora coerulea on Ishigaki Island, southwest Japan. Coral Reefs 22:188-196

Harmelin JG, Marinopoulos J (1994) Population structure and partial mortality of the gorgonian Paramuricea clavata (Risso) in the North-Western Mediterranean (France, Port-Cros Island). Mar Life 4:5-13

Harrison PL (2011) Sexual reproduction of scleractinian corals. In: Dubinsky Z, Stambler N (eds) Coral reefs: an ecosystem in transition. Springer, Dordrecht, p 59-85

Harrison PL, Wallace CC (1990) Reproduction, dispersal and recruitment of scleractinian corals. In: Dubinsky Z (ed) Coral reefs. Elsevier, Amsterdam, p 133-207

> Hwang SJ, Song JI (2007) Reproductive biology and larval development of the temperate soft coral Dendronephthya gigantea (Alcyonacea: Nephteidae). Mar Biol 152: 273-284

> Jackson JBC (1977) Competition on marine hard substrata: the adaptive significance of solitary and colonial strategies. Am Nat 111:743-767

Jackson JBC (1979) Morphological strategies of sessile animals. In: Larwood GP, Rosen BR (eds) Biology and systematics of colonial organisms. Academic Press, New York, NY, p 499-555

Kahng SE, Benayahu Y, Lasker HR (2011) Sexual reproduction in octocorals. Mar Ecol Prog Ser 443:265-283

Linares C, Coma R, Zabala M (2008) Effects of a mass mortality event on gorgonian reproduction. Coral Reefs 27: 27-34

Lloret J (2003) Proposta de regulació del busseig amb escafandre al parc natural de Cap de Creus. Report No. 019903. Generalitat de Catalunya, Departament de Medi Ambient, Barcelona

Lo Bianco S (1909) Notizie biologique risguardanti specialmente il periodo di maturita sessuale degli animali del Golfo di Napoli. Mitt Zool Stn Neapel 19:513-761

McFadden CS (1999) Genetic and taxonomic relationships among Northeastern Atlantic and Mediterranean populations of the soft coral Alcyonium coralloides. Mar Biol 133:171-184

> McFadden CS, Donahue R, Hadland BK, Weston R (2001) A molecular phylogenetic analysis of reproductive trait evolution in the soft coral genus Alcyonium. Evolution 55:54-67

Paine RT (1974) Intertidal community structure. Oecologia 15:93-120

$>$ Pequegnat WE (1964) The epifauna of a California siltstone reef. Ecology 45:272-283

> Previati M, Palma M, Bavestrello G, Falugi C, Cerrano C (2010) Reproductive biology of Parazoanthus axinellae (Schmidt,1862) and Savalia savaglia (Bertoloni, 1819) (Cnidaria, Zoantharia) from the NW Mediterranean coast. PSZNI: Mar Ecol 31:555-565

Editorial responsibility: Ferdinando Boero,

Lecce, Italy
Ribes M, Coma R, Rossi S, Micheli M (2007) Cycle of gonadal development in Eunicella singularis (Cnidaria: Octocorallia): trends in sexual reproduction in gorgonians. Invertebr Biol 126:307-317

Ros JD, Romero J, Ballesteros E, Gili JM (1985) Diving in blue water. The benthos. In: Margalef R (ed) Key environments. Western Mediterranean. Pergamon Press, Oxford, p 233-295

Rossi S, Gili JM (2009) Reproductive features and gonad development cycle of the soft bottom-gravel gorgonian Leptogorgia sarmentosa (Esper, 1791) in the NW Mediterranean Sea. Invertebr Reprod Dev 53:175-190

Rossi S, Snyder MJ, Gili JM (2006) Protein, carbohydrate, lipid concentrations and HSP 70- HSP 90 (stress protein) expression over an annual cycle: useful tool to detect feeding constraints in a benthic suspension feeder. Helgol Mar Res 60:7-17

> Rossi S, Bramanti L, Broglio E, Gili JM (2012) Trophic impact of long-lived species indicated by population dynamics in the short-lived hydrozoan Eudendrium racemosum. Mar Ecol Prog Ser 467:97-111

> Ryland JS, Babcock RC (1991) Annual cycle of gametogenesis and spawning in a tropical zoanthid, Protopalythoa sp. Hydrobiologia 216-217:117-123

Ryland JS, Westphalen D (2004) The reproductive biology of Parazoanthus parasiticus (Hexacorallia: Zoanthidea) in Bermuda. Hydrobiologia 530-531:411-419

> Ryland JS, de Putron S, Scheltema RS, Chimonides PJ, Zhadan DG (2000) Semper's (zoanthid) larvae: pelagic life, parentage and other problems. Hydrobiologia 440: 191-198

Sebens KP (1991) Habitat structure and community dynamics in marine benthic systems. In: Bell SS, McCoy ED, Mushinsky HR (eds) Habitat structure: the physical arrangement of objects in space. Chapman \& Hall, London, p 211-234

Sinniger F, Reimer JD, Pawlowski J (2010) The Parazoanthidae (Hexacorallia: Zoantharia) DNA taxonomy: description of two new genera. Mar Biodivers 40:57-70

> Tsounis G, Rossi S, Gili JM, Arntz W (2006) Population structure of an exploited benthic cnidarian: the case study of red coral (Corallium rubrum L.). Mar Biol 149:1059-1070

> Tsounis G, Martinez L, Bramanti L, Viladrich N, Gili JM, Martinez A, Rossi S (2012) Anthropogenic effects on reproductive effort and allocation of energy reserves in the Mediterranean octocoral Paramuricea clavata. Mar Ecol Prog Ser 449:161-172

> Vance R (1973) On reproductive strategies in marine benthic invertebrates. Am Nat 107:339-352

- Wahl M (1989) Marine epibiosis. I. Fouling and antifouling: some basic aspects. Mar Ecol Prog Ser 58:175-189

Weinberg S (1977) Revision of the common Octocorallia of the Mediterranean circalittoral II. Alcyonacea. Beaufortia 25:131-166

Wendt PH, van Dolah RF, O'Rourke CB (1985) A comparative study of the invertebrate macrofauna associated with seven sponge and coral species collected from the South Atlantic Bight. J Elisha Mitchell Sci Soc 101:187-203

Witman JD, Dayton PK (2001) Rocky subtidal communities. In: Bertness MD, Gaines SD, Hay ED (eds) Marine community ecology. Sinauer Associates, Sunderland, MA, p 339-366

Submitted: July 17, 2012; Accepted: January 15, 2013 Proofs received from author(s): March 5, 2013 